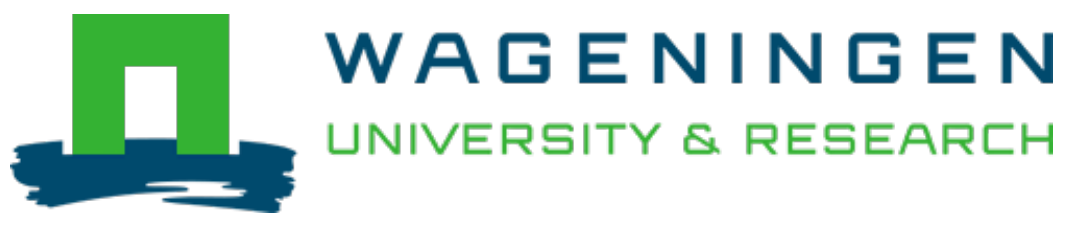

\title{
Effect of processing conditions on the formation of biogenic amines and ethyl carbamate in soybean tempe
}

\author{
Journal of food safety \\ Nout, M.J.R.; Ruikes, M.M.W.; Bouwmeester, H.M.; Beljaars, P.R. \\ https://doi.org/10.1111/j.1745-4565.1993.tb00114.x
}

This publication is made publicly available in the institutional repository of Wageningen University and Research, under the terms of article $25 \mathrm{fa}$ of the Dutch Copyright Act, also known as the Amendment Taverne. This has been done with explicit consent by the author.

Article 25 fa states that the author of a short scientific work funded either wholly or partially by Dutch public funds is entitled to make that work publicly available for no consideration following a reasonable period of time after the work was first published, provided that clear reference is made to the source of the first publication of the work.

This publication is distributed under The Association of Universities in the Netherlands (VSNU) 'Article $25 \mathrm{fa}$ implementation' project. In this project research outputs of researchers employed by Dutch Universities that comply with the legal requirements of Article $25 \mathrm{fa}$ of the Dutch Copyright Act are distributed online and free of cost or other barriers in institutional repositories. Research outputs are distributed six months after their first online publication in the original published version and with proper attribution to the source of the original publication.

You are permitted to download and use the publication for personal purposes. All rights remain with the author(s) and / or copyright owner(s) of this work. Any use of the publication or parts of it other than authorised under article $25 \mathrm{fa}$ of the Dutch Copyright act is prohibited. Wageningen University \& Research and the author(s) of this publication shall not be held responsible or liable for any damages resulting from your (re)use of this publication.

For questions regarding the public availability of this publication please contact openscience.library@wur.nl 


\title{
EFFECT OF PROCESSING CONDITIONS ON THE FORMATION OF BIOGENIC AMINES AND ETHYL CARBAMATE IN SOYBEAN TEMPE
}

\author{
M.J.R. NOUT ${ }^{1}$, M.M.W. RUIKES and H.M.BOUWMEESTER \\ Department of Food Science \\ Agricultural University \\ Bomenweg 2, 6703 HD Wageningen \\ The Netherlands \\ and P.R. BELJAARS \\ Inspectorate for Health Protection \\ Food Inspection Service \\ P.O.Box 2516 \\ 6201 GA Maastricht \\ The Netherlands \\ Received for Publication May 25, 1993 \\ Accepted for Publication August 19, 1993
}

\begin{abstract}
Tempe is a fermented soybean product originating from Indonesia. The effects of manufacturing conditions, i.e., soaking, boiling, fermentation and home cooking by stewing or frying, and the effect of pure cultures of microorganisms commonly occurring in tempe towards their production of toxicants like biogenic amines and ethyl carbamate were investigated. The level of biogenic amines in soaked soybeans was rather low (total $<280 \mathrm{ppm}$ ), and not significantly affected by boiling, but considerably increased by fermentation. The functional fungus Rhizopus oligosporus mainly produced tyramine and some putrescine (total biogenic amines approximately 1800 ppm). With added inoculation of Klebsiella pneumoniae and Trichosporon beigelii, the total amount of biogenic amines increased slightly (2000, resp. 2100 ppm) with a shift towards cadaverine. With added Lactobacillus plantarum, a reduction of tyramine levels resulted in a considerably lower total level of biogenic amines (approx. $1000 \mathrm{ppm}$ ). Storage at $5 \mathrm{C}$ did not affect the level of biogenic amines, whereas at $25 \mathrm{C}$, increased levels of putrescine were observed. Home cooking by stewing had little effect, but frying in oil resulted in significant decreases of both
\end{abstract}

'corresponding author

Journal of Food Safety 13 (1993) 293-303. All Rights Reserved.

Copyright 1993 by Food \& Nutrition Press, Inc., Trumbull, Connecticut. 
putrescine and tyramine. Preventive measures to keep biogenic amines at low levels in tempe are recommended. They include inoculation with selected lactic acid bacteria which cannot produce but can degrade biogenic amines, and frying instead of stewing of tempe. Ethyl carbamate levels were negligible $(<11 \mathrm{ppb})$ in all treatments; this was attributed to the absence of significant concentrations of ethanol in the product.

\section{INTRODUCTION}

Biogenic amines and ethyl carbamate are toxic substances which can be generated in foods, mainly by microbial enzymatic activity. Biogenic amines of toxicological relevance include histamine, tyramine, $\beta$-phenylethylamine, tryptamine, putrescine and cadaverine (Stratton $e$ t al. 1991). The major pathway of formation in foods is by decarboxylation of free amino acids. Various lactic acid bacteria and Enterobacteriaceae possess the required decarboxylase activity (Stratton et al. 1991). No data are available on the production of decarboxylases by fungi.

Ethyl carbamate (urethane) has mutagenic and carcinogenic properties (Mirvish 1986), and can be formed from reaction with ethanol and naturally occurring carbamyl phosphate during the fermentation process. Both compounds mainly result from yeast metabolism; ethyl carbamate can also be formed by the reaction of ethanol and urea produced naturally from amino acids like arginine and citrulline (Ough 1976). The latter compound was found to accumulate in raw soy sauce and act as a major precursor for ethyl carbamate formation during the pasteurization operation (Matsudo et al. 1993).

Tempe is a fermented food of Indonesian origin obtained by fungal solid-substrate fermentation of soaked and cooked soybeans, legumes, cereals or other suitable raw materials (Ko and Hesseltine 1979; Nout and Rombouts 1990). The manufacturing process of soybean tempe includes soaking of the dehulled beans in water overnight, followed by boiling or steaming. After discarding the water, the beans are allowed to air-dry and cool, and accordingly inoculated with spore preparations of Rhizopus spp., usually R.oligosporus. Fermentation of the inoculated beans takes place in perforated containers.

In addition to filamentous fungi, considerable levels of bacteria and yeasts occur in tempe as a result of cross-contamination from equipment, use of impure inoculum, etc. Lactic acid bacteria, e.g., Lactobacillus plantarum prevail in tempe when lactic fermentation takes place during the soaking stage (Nout $e t$ al. 1987). Enterobacteriaceae are also common in tempe and some of them, e.g., Klebsiella pneumoniae have been associated with the production of vitamin B12 in tempe (Okada et al. 1985). Yeasts, e.g., Trichosporon beigelii occur in varying quantities (Samson et al. 1987). Due to the continuing microbial and 
enzymic activity, freshly harvested tempe has a limited shelf-life and should preferably be prepared for consumption the same day or be kept refrigerated. Home preparation prior to consumption consists of cooking, e.g., by boiling in stew or by frying in oil.

The presence of varying levels of biogenic amines in cheese, sausage, wine, beer, soy sauce and miso (Stratton et al. 1991), and of ethyl carbamate in distilled spirits and wines, and fermented foods such as bread, soy sauce, miso and yeast spread (Diachenko et al. 1992) have been reported. In the absence of data concerning tempe, the present investigation was carried out to evaluate the influence of processing, and of representative microorganisms on the possible formation of biogenic amines and ethyl carbamate in tempe prepared from soybeans.

\section{MATERIALS AND METHODS}

\section{Microorganisms}

Inocula used included Rhizopus oligosporus (NRRL5905 = LUW575) grown on Malt Extract Agar (MEA; Oxoid CM59) at 30C for 1 week, Klebsiella pneumoniae (isolated from commercial tempe) grown on Plate Count Agar (Oxoid CM325) at 30C for $24 \mathrm{~h}$, Trichosporon beigelii (isolated from commercial tempe; LUW692) grown on MEA at 30C for 3 days, and Lactobacillus plantarum (Pioneer RG1) grown on de Man, Rogosa \& Sharpe (MRS) agar (Merck 10661 with $1.2 \%$ technical agar Oxoid L13) at $30 \mathrm{C}$ for 24 h. Microbiological analyses for total mesophilic aerobic bacteria, Enterobacteriacaea, yeasts and lactic acid bacteria were carried out in freshly prepared samples in duplicate, according to Nout et al. (1987a).

\section{Tempe Manufacture}

Tempe was manufactured from dry abrasion-dehulled yellow variety soybeans at a laboratory scale (Nout et al. 1987a) with different soaking conditions and inoculations with starter organisms. Soaking conditions included (1) $4 \mathrm{C}$ overnight to allow hydration while avoiding microbial activity; (2) $30 \mathrm{C}$ overnight to allow spontaneous fermentation (Nout et al. 1987b); and (3) inoculation with $10 \% \mathrm{v} / \mathrm{v}$ of fermented soaking water from a previous batch and incubation at $30 \mathrm{C}$ overnight to achieve accelerated natural fermentation (Nout et al. 1987b). After the usual boiling treatment, the soybeans were sterilized by dispensing them in $100 \mathrm{~g}$ portions in screw-capped glass jars followed by autoclave treatment at $121 \mathrm{C}$ for $30 \mathrm{~min}$. Sterilization is not a normal part of the tempe production process, but it was incorporated to enable an assessment of the single and combined effects of added pure cultures of tempe-associated microorganisms. In all treatments, Rhizopus oligosporus sporangiospores were 
added $\left(10^{9} \mathrm{cfu} / \mathrm{Kg}\right.$ cooked beans) as the functional starter. Additional inoculation with Klebsiella pneumoniae, Trichosporon beigelii and Lactobacillus plantarum was at rather high levels (approximately $10^{8} \mathrm{cfu} / \mathrm{Kg}$ cooked beans) to ensure maximum effect. In trade practice, perforated PVC lunch boxes are used to incubate the inoculated beans. As these cannot be sterilized, we incubated the inoculated beans at $30 \mathrm{C}$ for $44 \mathrm{~h}$ in the glass jars in which they had been autoclaved, and a perforated polyethylene film was used to cover the jars.

\section{Commercial Tempe}

Commercial tempe of good quality was purchased from a local retailer in Wageningen. It was used for boiling and frying on the day of purchase, and duplicate samples were stored at $25 \mathrm{C}$ for 1 week, and at $5 \mathrm{C}$ for 2 weeks in their original polyethylene wrapping. In case of boiling, cubes of $1 \mathrm{~cm}^{3}$ were immersed in boiling water during $10 \mathrm{~min}$; for frying, slices of $5 \mathrm{~mm}$ thickness were immersed in sunflower oil at $170 \mathrm{C}$ until they were golden-brown (3-5 min) and excess oil was removed using absorbent paper.

Samples for chemical analysis were prepared by grinding $100 \mathrm{~g}$ of composite sample from duplicate treatments, followed by frozen storage at $-20 \mathrm{C}$ until analysis. Chemical analyses were carried out in duplicate.

\section{Determination of Biogenic Amines}

A portion of $15 \mathrm{~g}$ dry matter was homogenized with $50 \mathrm{ml} 5 \%$ trichloroacetic acid at $70 \mathrm{C}$ in a $100 \mathrm{ml}$ glass beaker using a Waring Blendor. After cooling to room temperature, the mixture was transferred quantitatively into a $100 \mathrm{ml}$ volumetric flask and made up to the mark with $5 \%$ trichloroacetic acid. After mixing, a $50 \mathrm{ml}$ portion was transferred into a centrifuge tube and centrifuged at $2500 \mathrm{~g}$ for $10 \mathrm{~min}$. The supernatant was filtered through filter paper (Schleicher and Schull $5951 / 2, \mathrm{nr} .311645$ ). A $25 \mathrm{ml}$ aliquot of filtrate was transferred into a $100 \mathrm{ml}$ volumetric flask and diluted to the mark with distilled water. The diluted filtrate was filtered again through a $0.45 \mu \mathrm{m}$ pore size filter (Millipore filter, type HVLP 04700). Biogenic amines were separated by ion exchange liquid chromatography (LC) and detected with a fluorescence detector after post-column derivatization with o-phthalaldehyde adapted from Walters (1984). The detection limit was $1 \mathrm{mg} / \mathrm{Kg}$, and data have a coefficient of variation of $10 \%$. The LC conditions were as follows: column: stationary phase Zorbax 300 SCX strong cation exchange resin (DuPont nr. 28768); mobile phase (eluent): 70 vol. parts of $0.1 \mathrm{M}$ phosphate buffer $\mathrm{pH} 6.1$ and $30 \mathrm{vol}$. parts of methanol; elution rate: $1.0 \mathrm{ml} / \mathrm{min}$. Post-column derivatization was carried out at $45 \mathrm{C}$ in a $900 \times 0.5 \mathrm{~mm}$ i.d. Teflon reactor spiral. The reagent for post-column derivatization was added at $0.8 \mathrm{ml} / \mathrm{min}$ and consisted of freshly mixed solutions of A and B. Solution A: $12.5 \mathrm{~g}$ boric acid (Merck art.165) in 
$475 \mathrm{ml}$ distilled water adjusted with $\mathrm{KOH}$ to $\mathrm{pH} 10.4$. Solution $\mathrm{B}: 300 \mathrm{mg}$ o-phthalaldehyde (Merck art. 11452) in $5 \mathrm{ml}$ ethanol 96\% (Merck art. 983) to which $100 \mu 1$ 2-mercaptoethanol (Merck art. 805740) was added. Detection was carried out with a fluorescence detector (Waters type 420 with lamp 78245) with $\lambda_{\text {exciation }}=338 \mathrm{~nm}$ and $\lambda_{\text {emission }}>420 \mathrm{~nm}$.

\section{Detection of Ethyl Carbamate}

Ten grams of sample were homogenized and extracted with methylene chloride according to the procedure for bread (Canas et al. 1989). Concentrated extracts were analyzed by gas liquid chromatography (GLC) according to Kesselmans et al. (1986), applying the following conditions: column: CPWax-52 CB, WCOT fused silica length $50 \mathrm{~m}$, inner diameter $0.32 \mathrm{~mm}$; carrier $\mathrm{N}_{2}(120 \mathrm{kPa})$, make-up $\mathrm{He}(115 \mathrm{kPa})$, detector $\mathrm{H}_{2}(67 \mathrm{kPa})$, air $(102 \mathrm{kPa})$; injection volume $1.0 \mu \mathrm{l}$ on-column; temperature program: $20 \mathrm{C}$ for $20 \mathrm{~s}, 20-87 \mathrm{C}$ in $40 \mathrm{~s}, 87-180 \mathrm{C}$ at a rate of $8 \mathrm{C}$ per $\mathrm{min}, 180-190 \mathrm{C}$ at a rate of $10 \mathrm{C} / \mathrm{min}, 190 \mathrm{C}$ for $20 \mathrm{~min}$. The recoveries for ethyl carbamate (EC) in spiked tempe samples varied from 45 to $50 \%$. The detection limit of EC in extract by GLC was 10 $\mu \mathrm{g} / \mathrm{L}$, corresponding with $11 \mu \mathrm{g} / \mathrm{Kg}(11 \mathrm{ppb})$ in the original sample. Data have a coefficient of variation of $5.5 \%$ at $200 \mathrm{ppb}$ level.

\section{RESULTS AND DISCUSSION}

Table 1 shows the effect of preparatory soaking and boiling treatments involved in the tempe manufacturing process, and the levels of cadaverine, histamine, putrescine, tryptamine and tyramine expressed as $\mathrm{mg} / \mathrm{Kg}$ sample dry weight.

When soaking took place at $4 \mathrm{C}$ (treatment $\mathrm{A}$ ), no bacterial fermentation occurred, as indicated by the high $\mathrm{pH} 6.5$ which is close to the original $\mathrm{pH}$ of soybeans. At $30 \mathrm{C}$ (treatment $\mathrm{B}$ ), spontaneous bacterial fermentation resulted in a modest decrease to $\mathrm{pH} 5.2$, while an active acidification till $\mathrm{pH} 4.4$ took place after inoculation (treatment $\mathrm{C}$ ). During the soaking stage at $4 \mathrm{C}$ a noticeable accumulation of tyramine takes place. This can be explained by the action of endogenous decarboxylases on free amino acids (tyrosine) in the soybeans (Devi and Prasad 1992). When actively growing microorganisms are present (treatments B and C), some of the free amino acids are not converted into biogenic amines. In addition, the decreased $\mathrm{pH}$ in the beans soaked at $30 \mathrm{C}$ may inhibit endogenous decarboxylases, as histidine decarboxylase has an optimum pH of approximately 6.5 (Janssen 1988). Spontaneously soaked beans usually contain a mixed microbial flora in which Enterobacteriaceae predominate 
whereas inoculated soaks contain mainly lactobacilli (Nout et al. 1987b). The levels of biogenic amines of soaked beans also differed with respect to putrescine and tyramine. However, the data do not allow conclusions to be made about the role of particular groups of microorganisms.

TABLE 1.

ACCUMULATION OF BIOGENIC AMINES (MG/KG DRY MATTER) DURING LABORATORY PREPARATION OF SOYBEAN TEMPE. EFFECT OF SOAKING AND BOILING.

\begin{tabular}{|c|c|c|c|c|}
\hline Treatment code: & A & B & & C \\
\hline Beans soaked at: & $4 \mathrm{C}$ & $30 \mathrm{C}$ & $30 \mathrm{C}$ & inoculated ${ }^{I}$ \\
\hline Cadaverine & $<17$ & $<17$ & & $<17$ \\
\hline Histamine & $<3$ & $<3$ & & $<3$ \\
\hline Putrescine & $<8$ & 67 & & 8 \\
\hline Tryptamine & $<3$ & $<3$ & & $<3$ \\
\hline Tyramine & 250 & 75 & & 167 \\
\hline \multicolumn{5}{|c|}{ After boiling $(30 \mathrm{~min} .100 \mathrm{c})$ : } \\
\hline Cadaverine & $<25$ & $<25$ & & $<25$ \\
\hline Histamine & $<5$ & $<5$ & & $<5$ \\
\hline Putrescine & $<13$ & 88 & & $<13$ \\
\hline Tryptamine & $<5$ & $<5$ & & $<5$ \\
\hline Tyramine & 200 & 113 & & 113 \\
\hline
\end{tabular}

1: inoculated with $10 \% \mathrm{v} / \mathrm{v}$ of soaking water from previous batch. 
Boiling had no significant effect on the levels of biogenic amines in the variously treated beans. Likewise, autoclaving only had a slight but insignificant decreasing effect (data not shown) on the level of tyramine in beans of treatment A.

TABLE 2.

ACCUMULATION OF BIOGENIC AMINES (MG/KG DRY MATTER) DURING LABORATORY PREPARATION OF SOYBEAN TEMPE. EFFECT OF FUNCTIONAL AND ASSOCIATIVE MICROORGANISMS

\begin{tabular}{llllll}
\hline Treatment code: & A1 & A2 & A3 & A4 & CI \\
Soaked at: & $4 \mathrm{C}$ & $4 \mathrm{C}$ & $4 \mathrm{C}$ & $4 \mathrm{C}$ & $\begin{array}{l}30 \mathrm{C} \\
\text { inocula } \\
\end{array}$ \\
& & & & ted $^{1}$
\end{tabular}

After fermentation with:

\begin{tabular}{|c|c|c|c|c|c|}
\hline$(45 \mathrm{~h}, 30 \mathrm{C})$ & R.oli. ${ }^{2}$ & $\begin{array}{l}\text { R.oli. } \\
+\mathrm{k} \cdot \mathrm{p} \cdot{ }^{3}\end{array}$ & $\begin{array}{l}\text { R.oli. } \\
+ \text { T.b. }\end{array}$ & $\begin{array}{l}\text { R.oli. } \\
+ \text { L.p. }\end{array}$ & $\begin{array}{l}\text { R.oli. } \\
+ \text { L.p. }\end{array}$ \\
\hline Cadaverine & $<25$ & 950 & 750 & $<25$ & $<25$ \\
\hline Histamine & $<5$ & $<5$ & $<5$ & $<5$ & $<5$ \\
\hline Putrescine & 163 & 125 & 150 & 88 & 225 \\
\hline Tryptamine & $<5$ & $<5$ & $<5$ & $<5$ & $<5$ \\
\hline Tyramine & 1575 & 900 & 1175 & 925 & 725 \\
\hline
\end{tabular}

1: inoculated with $10 \% \mathrm{v} / \mathrm{v}$ of soaking water from previous batch; 2 : R.oli.: Rhizopus oligosporus; 3: K.p.: Klebsiella pneumoniae; 4: T.b.: Trichosporon beigelii;

5: L.p.: Lactobacillus plantarum. 
In Table 2, the effect of incubation with pure culture inocula of functional and associative microorganisms is shown. Treatment $\mathrm{A}$ was chosen to serve as a versatile substrate for all microorganisms tested (A1-A4) as the neutral $\mathrm{pH}$ of the sterilized beans would enable their growth. In contrast, treatment $\mathrm{C}$ was also autoclaved but only inoculated with R.oligosporus + L.plantarum (C1). Microbiological analyses using selective media (data not shown) for Enterobacteriaceae, yeasts and filamentous fungi, and lactic acid bacteria confirmed that the tempe treatments $\mathrm{A} 1, \mathrm{~A} 2, \mathrm{~A} 3, \mathrm{~A} 4$ and $\mathrm{C} 1$ did not contain detectable levels of contaminating microorganisms other than the inoculated strains. Fermentation treatments caused a significant increase in levels of cadaverine, putrescine and tyramine. Comparing fresh tempe of treatments $A 1$, $\mathrm{A} 2, \mathrm{~A} 3$ and $\mathrm{A} 4$ it is clear that $R$.oligosporus itself can produce significant levels of putrescine and tyramine. In the presence of either K.pneumoniae or $T$.beigelii, reduced tyramine levels were found but due to a strong production of cadaverine, total levels of biogenic amines were even somewhat higher than with only R.oligosporus. With added L.plantarum, no such cadaverine accumulation was observed. Both L.plantarum inoculated treatments (A4 and C1) resulted in similar patterns of biogenic amines, i.e., mainly tyramine with some putrescine, with total biogenic amines well below that of treatment A1 (only R.oligosporus). These limited data suggest that the initial $\mathrm{pH}$ of the soaked soybeans did not play an important role in the formation of biogenic amines by L.plantarum.

Table 3 shows that the levels of biogenic amines in different samples of commercial tempe can be quite variable. Major factors causing such differences would include the microbiological composition and conditions and duration of storage.

Storage for 1 week at room temperature resulted in a significant increase of putrescine levels. Histamine and tyramine levels increased in one sample. On the other hand, storage for 2 weeks in the refrigerator did not result in increased levels of biogenic amines. In some cases there even was a slight decrease.

Home preparation by stewing caused some reduction of putrescine level whereas frying had stronger reducing effects on putrescine in both samples, and on histamine and tyramine in one sample.

Considering the total levels of biogenic amines of $1000-4000 \mathrm{mg} / \mathrm{kg}$ dry weight in samples of laboratory-made and commercial tempe, and an estimated amount of $50 \mathrm{~g}$ dry weight of tempe consumed per person per meal (Nout and Rombouts 1990), this corresponds to an intake of 50-200 mg total biogenic amines per meal. An intake of $>40 \mathrm{mg}$ biogenic amines per meal has been considered potentially toxic (Ayres et al. 1980). However, not all amines are equally toxic. Especially histamine and tyramine are of concern. Histamine was found at low levels, but tyramine was present in significant quantities. Consequently, all possible measures should be taken to reduce the level of 
biogenic amines when tempe is produced. Options are inoculation with actively growing lactic acid bacteria, selected for their inability to produce biogenic amines combined with an ability to degrade them (Beutling 1992). Frying in oil may also be expected to give a safer product compared to spontaneously fermented and stewed tempe.

TABLE 3.

EFFECT OF STORAGE AND PREPARATION ON LEVELS OF BIOGENIC AMINES (MG/KG DRY MATTER) IN COMMERCIAL SOY TEMPE.

\begin{tabular}{|c|c|c|c|c|c|c|}
\hline \multirow[b]{3}{*}{ Sample: } & \multirow{2}{*}{\multicolumn{2}{|c|}{ Fresh tempe }} & \multicolumn{2}{|c|}{ Storage } & \multicolumn{2}{|c|}{ storage } \\
\hline & & & \multicolumn{2}{|c|}{1 week, $25 \mathrm{C}$} & \multicolumn{2}{|c|}{2 weeks, 5} \\
\hline & I & II & $I$ & II & $I$ & II \\
\hline Cadaverine & $<5$ & 225 & $<5$ & 200 & $<22$ & 100 \\
\hline Histamine & $<5$ & 100 & $<4$ & 225 & $<4$ & $<25$ \\
\hline Putrescine & 475 & 3200 & 1510 & 4500 & 225 & 777 \\
\hline Tryptamine & $<5$ & & $<4$ & & $<4$ & \\
\hline \multirow[t]{2}{*}{ Tyramine } & 500 & 575 & 500 & 821 & 500 & 733 \\
\hline & & & \multicolumn{2}{|c|}{ Stewed ${ }^{1}$} & \multicolumn{2}{|c|}{ Fried ${ }^{2}$} \\
\hline Fresh tempe & sample: & & I & & I & II \\
\hline Cadaverine & & & $<25$ & & $<11$ & \\
\hline Histamine & & & $<5$ & & $<2$ & $<10$ \\
\hline Putrescine & & & 250 & & 90 & 218 \\
\hline Tryptamine & & & $<5$ & & $<2$ & \\
\hline Tyramine & & & 500 & & 200 & 632 \\
\hline
\end{tabular}

1: in excess water $10 \mathrm{~min}$ at $100 \mathrm{C} ; 2$ : in sunflower oil $3-5 \mathrm{~min}$ at $170 \mathrm{C}$ 
With regard to ethyl carbamate, all samples contained less than $11 \mathrm{ppb}$ (the detection limit). This appears to correspond with the reported absence of ethyl carbamate in a range of fermented foods in which yeasts were not involved as major population (Diachenko et al. 1992). Levels up to $84 \mathrm{ppb}$ (soy sauce) were found in fermented foods in which some alcoholic fermentation had taken place and an average of approximately $200 \mathrm{ppb}$ was reported for alcoholic beverages. Also, citrulline and arginine were reported to act as precursors for ethyl carbamate formation (Matsudo et al. 1993). The tolerance level of ethyl carbamate as applied in Canada varies from $30 \mathrm{ppb}$ in wines to $400 \mathrm{ppb}$ in distilled spirits (Diachenko et al. 1992). This implies that ethyl carbamate is not a factor of public health relevance in soybean tempe. Most likely, the absence of ethyl carbamate is due to inadequate levels of precursors or ethanol in the product.

\section{ACKNOWLEDGMENT}

We gratefully acknowledge the chromatographic assistance for biogenic amines by Mrs. D.P. Venema and Ir. P.C.H. Hollman of the State Institute for Quality Control of Agricultural Products RIKILT-DLO, Wageningen. We are also indebted to Mr. T.M.M. Rondags and Ir. L. Terwel of the Inspectorate for Health Protection, Food Inspection Services at Maastricht and Rotterdam, The Netherlands, respectively, for carrying out the chromatographic analyses for ethyl carbamate.

\section{REFERENCES}

AYRES, J.C., MUNDT, J.O. and SANDINE, W.E. 1980. Microbiology of Foods, p. 543, W.H. Freeman and Co., San Francisco.

BEUTLING, D. 1992. Prüfung von Starterorganismen auf ihre Befähigung zur Bildung von Histamin und Tyramin. Monatsh. Veter.-Med. 47, 587-591.

CANAS, B.J., HAVERY, D.C., ROBINSON, L.R., SULLIVAN, M.P., JOE, F.L., JR. and DIACHENKO, G.W. 1989. Ethyl carbamate levels in selected fermented foods and beverages. J. Assoc. Offic. Anal. Chemists 72, 873-876.

DEVI, S.R. and PRASAD, M.N.V. 1992. Effect of ferulic acid on growth and hydrolytic enzyme activities of germinating maize seeds. J. Chem. Ecol. $18,1981-1990$.

DIACHENKO, G.W., CANAS, B.J., JOE, F.L. and DINOVI, M. 1992. Ethyl carbamate in alcoholic beverages and fermented foods. In Food Safety Assessment (J.W. Finley, S.F. Robinson, and D.J. Armstrong, eds.) pp. 419-428. ACS Symposium Series No.484. American Chemical Society. 
JANSSEN, F.W. 1988. Biogenic amines. Occurrence and methods of analysis (in Dutch). De Ware(n)-Chemicus 18, 54-66.

KESSELMANS, R.P.W., COHEN, M., PEETERS, M.J. and BELJAARS, P.R. 1986. Survey of the presence of ethyl carbamate (urethan) in alcoholic beverages (in Dutch). De Ware(n)-Chemicus 16, 105-119.

KO, S.D. and HESSELTINE, C.W. 1979. Tempe and related foods. In Economic Microbiology Vol. 4, Microbial Biomass (A.H. Rose, ed.) pp. 115-140, Academic Press, London.

MATSUDO, T. et al. 1993. Determination of ethyl carbamate in soy sauce and its possible precursor. J. Agric. Food Chem. 41, 352-356.

MIRVISH, S.S. 1968. The carcinogenic action and metabolism of urethan and N-hydroxyurethan. Adv. Cancer Res. 11, 1-42.

NOUT, M.J.R., BEERNINK, G. and BONANTS-VAN LAARHOVEN, T.M.G. 1987a. Growth of Bacillus cereus in soybean tempeh. Int'1 J. Food Microbiol. 4, 293-301.

NOUT, M.J.R., DE DREU, M.A., ZUURBIER, A.M. and BONANTS-VAN LAARHOVEN, T.M.G. 1987b. Ecology of controlled soybean acidification for tempe manufacture. Food Microbiol. 4, 165-172.

NOUT, M.J.R. and ROMBOUTS, F.M. 1990. Recent developments in tempe research. J. Appl. Bacteriol. 69, 609-633.

OKADA, N., HADIOETOMO, R.S., NIKKUNI, S. and ITOH, H. 1985. Isolation of bacteria producing vitamin B12 from fermented soybean tempeh from Indonesia. Report of the National Food Research Institute [Shokuryo Kenkyusho Kenkyu Hokoku] no.46, 15-20.

OUGH, C.S. 1976. Ethyl carbamate in fermented beverages and foods. J. Agric. Food Chem. 24, 323-331.

SAMSON, R.A., VAN KOOIJ, J.A. and DE BOER, E. 1987. Microbiological quality of commercial tempeh in the Netherlands. J. Food Prot. 50, 92-94.

STRATTON, J.E., HUTKINS, R.W. and TAYLOR, S.L. 1991. Biogenic amines in cheese and other fermented foods - A review. J. Food Prot. 54, 460-470.

WALTERS, M.J. 1984. Determination of histamine in fish by liquid chromatography with post-column reaction and fluorometric detection. J. Assoc Offic. Anal. Chemists 67, 1040-1043. 